\title{
BARCODING DNA IKAN HIAS LAHAN GAMBUT
}

\author{
Melta Rini Fahmi\#, Anjang Bangun Prasetio, Ruby Vidia Kusumah, \\ Erma Primanita Hayuningtyas, dan Idil Ardi
}

Balai Penelitian dan Pengembangan Budidaya Ikan Hias

\begin{abstract}
ABSTRAK
Perairan gambut merupakan ekosistem unik yang memiliki kekayaan biodiversitas ikan, sebagian besar di antaranya memiliki potensi sebagai ikan hias. Penelitian ini dilakukan untuk melakukan identifikasi dan analisis keragaman genetik, karakter genetik, jarak genetik, dan pohon kekerabatan ikan-ikan yang mendiami perairan gambut Cagar Biosfere Bukit Batu Provinsi Riau. Tahap pertama penelitian ini adalah identifikasi secara morfologi terhadap 29 ikan hasil koleksi yang potensial sebagai ikan hias. Selanjutnya amplifikasi dan alignment 675 bp (base pair) dari 90 runutan parsial cytochrome c oxidase subunit 1 (COI). Hasil penelitian menunjukkan ikan yang diidentifikasi dapat dikelompokkan menjadi enam famili, yaitu Balontidae terdiri atas tiga spesies (12,5\%); Cyprinidae 13 spesies $(54,17 \%$; Cobitidae satu spesies $(4,17 \%$; Siluridae dua spesies (8,3\%); Datnoidae satu spesies (4,17\%); dan Bagridae empat spesies (16,67\%). Beberapa spesies memiliki perbedaan genetik intraspesies lebih dari 3\% Analisis kekerabatan dan clustering ikan hias lahan gambut berdasarkan gen COI memiliki nilai bootstrap 87-99 per ulangan.
\end{abstract}

\section{KATA KUNCl: barcoding DNA; ikan hias; lahan gambut; keragaman genetik}

ABSTRACT: DNA barcoding of ornamental fish from peat lands. By: Melta Rini Fahmi, Anjang Bangun Prasetio, Ruby Vidia Kusumah, Erma Primanita Hayuningtyas, and Idil Ardi

Peat is a unique ecosystem which a high fish biodiversity, and most of them are potential as ornamental fish. This research was conducted to identify and analyze genetic diversity, genetic code, genetic distances, and phylogenies of the fish that inhabit in the Bukit Batu Biosfere Reserves, Riau Province. The first stage of this study was identification of 29 fish species that potential as ornamental fish by using morphological character. The further stages were amplification and alignment of 675 base pairs of 90 partial sequences of cytochrome c oxidase subunit 1 (COI). Results showed that the identification based on COI could be classified into six families. These Families were Balontidae, Cyprinidae, Cobitidae, Siluridae, Datnoidae, and Bagridae which consist of three species $(12.5 \%)$, 13 species $(54.17 \%)$, one species $(4.17 \%)$, two species $(8.3 \%$, one species $(4.17 \%$, and four species $(16.67 \%$, respectively. Some clustered have intraspecies genetic divergence more than 3\% Phylogenetic and clustering analysis showed all of the OTU (Operational Taxonomic Unit) has a high bootstrap permutation of 87-99.

\section{KEYWORDS: DNA barcoding; ornamental fish; peat land; genetic diversity}

\section{PENDAHULUAN}

Pada tahun 2003, Paul Hebert dari University of Guelph, Ontario, Kanada, menerbitkan sebuah makalah di Proceedings of Royal Society yang menyebutkan gen cytochrome oxydase (COI) dapat berfungsi sebagai barcode genetik untuk semua makhluk hidup (Hebert et al., 2003). Semenjak dekade tersebut proyek barcode hampir semua mahluk hidup pun dimulai, dengan perkembangan teknologi, barcoding DNA juga dimanfaatkan sebagai gen tunggal atau lokus untuk

\footnotetext{
\# Korespondensi: Balai Penelitian dan Pengembangan Budidaya Ikan Hias. Jl. Perikanan No. 13, Pancoran Mas, Depok 16436, Indonesia. Tel.: + (021) 7520482 E-mail: meltarini.fahmi@kkp.go.id
}

identifikasi taksonomi, serta penentuan batasan spesies (Taylor \& Harrist, 2012). Peran barcode DNA sebagai alat (tool) identifikasi telah memberikan banyak kontribusi seperti identifikasi ikan pada stadia larva hingga dewasa, hingga evaluasi lalu lintas perdagangan ikan (Rasmussen et al., 2009).

Hubert et al. (2015) menyebutkan sebanyak 1.172 spesies ikan telah mendiami perairan Indonesia namun keberadaan ikan-ikan tersebut sebagian besar berada dalam kondisi terancam punah dan salah satu penyebabnya adalah perdagangan ikan hias langsung dari hasil tangkapan di alam. Laju eksplotasi yang tidak berimbang dengan upaya budidaya telah menjadi ancaman kepunahan beberapa jenis ikan terutama yang mendiami perairan gambut (peatland). Lahan 
gambut merupakan salah satu habitat yang dihuni oleh banyak jenis ikan hias sehingga dijuluki sebagai 'homeland of ornamental fish". Hutan dan lahan gambut merupakan ekosistem unik karena terbentuk dari timbunan serasah yang terdegradasi secara anaerob, air gambut cenderung bersifat asam ( $\mathrm{pH} 3-5$ ), berwarna hitam, miskin hara dan sangat kaya bahan organik (Giam et al., 2012).

Sundaland merupakan salah satu dari 26 spot biodiversitas di dunia, yang meliputi Malay Paninsula, Jawa, Kalimantan, dan Sumatera, serta Sundaland memiliki wilayah gambut sebesar $36 \%\left(160.000 \mathrm{~km}^{2}\right)$ (Miettinen \& Liew, 2010; Page et al., 2011). Beberapa dekade terakhir mulai diketahui ikan-ikan yang mendiami perairan gambut adalah ikan-ikan yang memiliki kemampuan adaptasi yang sempit (stenotopic) (Ng et al., 1994). Keberadaan ikan-ikan stenotopic pada saat ini mulai berada pada kondisi terancam punah karena intensitas kegiatan agroindustri yang cenderung monokultur di wilayah tersebut. Giam et al. (2012) memperkirakan laju kepunahan ikan-ikan yang mendiami perairan gambut saat ini mencapai $77 \%$ (72 dari 102) spesies stenotopic telah mencapai kondisi punah.

Mary et al. (2011) menyebutkan lahan gambut dihuni oleh kurang lebih 219 spesies dan 80 spesies di antaranya adalah ikan-ikan yang endemik di perairan tersebut. Lebih lanjut dijelaskan bahwa sebagian besar ikan-ikan yang mendiami perairan gambut baru berhasil diidentifikasi secara intensif setelah 20 tahun terakhir yaitu saat ilmu biologi mengalami revolusi menjadi biologi molekuler. Dengan ditemukannya gen cytochrome c oxidase subunit 1 (COI) sebagai penanda dan identifikasi spesies, maka revolusi pada dunia biodiversitas pun dimulai.

DNA barcoding adalah sebuah sistem yang dirancang untuk menyediakan proses identifikasi yang akurat, cepat, dan bersifat otomatis untuk semua spesies, karena menggunakan lokus atau gen pendek dan mutasi pada nukleotida pada lokus tersebut menjadi standar taksonomi masing-masing spesies (Hebert et al., 2003). Pada awalnya penemuan DNA barcoding ditujukan untuk kegiatan taksonomi ikan, namun saat ini DNA barcoding berkembang untuk konservasi genetik yang mengacu pada keragaman genetik intrainter-spesies. Keragaman spesies menggambarkan dinamika fenotipe selama proses ontogeni yang sangat dipengaruhi oleh kondisi lingkungan (Blaxter, 2003; Tautz et al., 2002). Beberapa keutamaan DNA barcoding dibandingkan dengan identifikasi secara morfologi adalah (1) pada identifikasi secara morfologi sering terjadi tumpang tindih beberapa karakter dengan taksa terdekat sehingga ini sering menjadi kendala dalam identifikasi; (2) DNA barcoding dapat digunakan untuk identifikasi semua stadia perkembangan ikan mulai dari telur hingga dewasa; (3) fenomena cryptic spesies dan criptic diversity, lebih banyak diungkap dengan menggunakan DNA barcoding.

Mengacu pada fenomena ikan-ikan yang mendiami perairan gambut cenderung berada pada kondisi terancam punah dan perkembangan teknologi DNA barcoding, maka perlu dilakukan upaya assessment secara cepat terkait potensi dan keragaman ikan di lahan gambut saat ini untuk kegiatan konservasi. Oleh karena itu, penelitian ini bertujuan untuk melakukan identifikasi secara molekuler spesies ikan-ikan yang mendiami perairan gambut di Provinsi Riau dan Jambi menggunakan gen COI parsial DNA mitokondria melalui penanda genetik (identitas spesies), karakter genetik, jarak genetik, dan pohon kekerabatan genetik.

\section{BAHAN DAN METODE}

\section{Koleksi Sampel}

Koleksi sampel dilakukan di perairan gambut Provinsi Riau dan Jambi. Sampel ikan ditangkap dengan menggunakan alat tangkap serokan, jaring lempar, pancing, dan anco. Ikan yang tertangkap didokumentasikan selanjutnya disimpan dalam formalin untuk proses identifikasi karakter morfometrik dan merisktik (Kotellat et al., 1993; Robert, 1989) dan sebagian lagi disimpan dalam alkohol 70\% untuk kegiatan molekuler.

\section{Ekstraksi dan Amplifikasi DNA}

Isolasi DNA dilakukan dengan menggunakan metode spin-column mengacu pada prosedur kerja Kit gSYNC DNA Extrasion yang dikeluarkan oleh perusahaan Geneaid. DNA hasil ekstraksi dimigrasikan pada gel agarose 1,2\% dalam larutan 1x TAE dengan pewarna DNA berupa cyber safe (tuliskan produsennya). DNA total divisualisasi dengan bantuan blue light transilluminator $(\lambda=250 \mathrm{~nm})$. DNA total hasil purifikasi digunakan sebagai DNA cetakan untuk proses amplifikasi dengan teknik Polymerase Chain Reaction (PCR). Primer yang digunakan adalah F15'-TCA-ACCAAC-CAC-AAA-GAC-ATT-GGA-C-3' (forward) dan R15'TAG-ACT-TCT-GGG-TGG-CCA-AAG-AAT-CA-3' (reverse) dengan target produk PCR sepanjang $707 \mathrm{pb}$ (Ward et al., 2005). Kondisi PCR yang digunakan adalah pra-PCR $\left(94^{\circ} \mathrm{C}\right.$ selama lima menit), denaturasi $\left(94^{\circ} \mathrm{C}\right.$ selama 30 detik), annealing atau penempelan $\left(52^{\circ} \mathrm{C}\right.$ selama 30 detik), ekstensi atau pemanjangan $\left(72^{\circ} \mathrm{C}\right.$ selama 30 detik), dan post-PCR $\left(72^{\circ} \mathrm{C}\right.$ selama lima menit). Runutan nukleotida hasil PCR selanjutnya dibaca dengan menggunakan Applied Biosystems melalui $1^{\text {st }}$ BASE DNA Sequencing Division. 


\section{Analisis Data}

Sisi homolog runutan nukleotida gen COI DNA mitokondria dari spesies yang diperoleh selanjutnya disejajarkan (multiple alligment). Analisis penanda genetik, keragaman genetik, jarak genetik, dan konstruksi pohon kekerabatan dari runutan nukleotida gen parsial COI DNA mitokondria dilakukan mengunakan program MEGA versi 5 (Tamura et al., 2011).

\section{DNA Barcoding Library}

Keberhasilan program DNA barcoding sangat bergantung pada pengembangan pustaka acuan DNA barcoding untuk tujuan identifikasi secara otomatis melalui sebuah sistem yang dikenal dengan Barcode of Life Datasystem (BOLD) yang menghimpun tujuh elemen data, meliputi: (1) nama spesies melalui identifikasi secara morfologi dan foto spesimen, (2) spesimen voucher, (3) lokasi geografis tempat koleksi sampel, (4) lembaga atau personal yang melakukan identifikasi, (5) runutan gen COI sekitar 500 bp, (6) primer yang digunakan untuk amplifikasi, dan (7) sistem pelacakan data.

\section{HASIL DAN BAHASAN}

\section{Keragaman Genetik Gen COI}

Sebanyak 707 bp runutan basa dari 90 runutan (sequence) disejajarkan (alignment), dengan menggunakan Crustal W program, dan hanya 675 bp yang dapat digunakan untuk analisis lebih lanjut. Jarak evolusi antar grup yang dihitung berdasarkan subtitusi nukleotida secara keseluruhan adalah 0,2327 (23,27\% . Matrik subtitusi nukleotida semua grup disajikan pada Tabel 1. Berdasarkan analisis dengan menggunakan HKY + G + I model terdapat distribusi yang tidak merata untuk semua nukleotida dengan frekuensi sebagai berikut: adenin (A) sebesar 25,46\% timin (T) sebesar $30,54 \%$ guanin (G) sebesar $26,27 \%$ dan yang paling sedikit adalah sitosin (C) sebesar $17,73 \%$
Perbandingan antara transisi dan transfersi adalah 1,968 untuk puri, dan 2,872 untuk pirimidin, secara keseluruhan perbandingan transisi dan transfersi adalah 1,301 .

Kelompok monopiletik secara taksonomi terbentuk jika spesimen-spesimen yang dianalisis memiliki perbedaan genetik lebih dari 3\%(Paul et al., 2003). Jarak genetik antar grup berdasarkan K2P (Kimura 2 Parameter) disajikan pada Lampiran 1. Dari Lampiran 1 diketahui bahwa jarak genetik antara kelompok Seluang bintik dan Seluang tasik serkap (dikenal dengan sebutan Rasbora merah) adalah 0,5\% Perbedaan genetik yang rendah ini menyebabkan spesimen tersebut berada pada dalam satu kelompok monopiletik. Demikian juga dengan Puntius petazona dan Puntius rombochelatus, walaupun secara taksonomi kedua ikan tersebut adalah dua spesies yang berbeda namun berdasarkan perbedaan genetik yang hanya 0,4\% maka kedua spesimen tersebut dikelompokkan menjadi menjadi satu klaster. Rendahnya perbedaan genetik antara Luceocephalus pulcer dan Epalzeorhynchos kalopterus diduga disebabkan oleh jumlah spesimen yang sangat sedikit (satu ekor).

Perbedaan genetik intra Operational Taxonomic Unit (OTU) atau grup Puntius hexazona, Seluang garis merah, Kryptopterus impok, Rasbora maculata lebih rendah dari 3\%menyebabkan keempat OTU tersebut tidak dikategorikan sebagai satu kelompok monopiletik. Sementara itu, 26 OTU lagi merupakan satu kelompok monopiletik karena perbedaan genetik intragrup (OTU) kurang dari 3\%

\section{Hubungan Kekerabatan Genetik}

Analisis kekerabatan dengan menggunakan program Neighbour-Joining NJ (1.000 bootstrap) mengindikasikan 87 spesies hasil analisis DNA barcoding dapat dikelompokkan menjadi enam famili, yaitu Balontidae terdiri atas tiga spesies (12,5\%) Cyprinidae 13 spesies $(54,17 \%)$; Cobitidae satu spesies $(4,17 \%)$; Siluridae dua spesies (8,3\%); Datnoidae satu

Tabel 1. Matrik substitusi nukleotida berdasarkan metode $H K Y+G+I$

Table 1. Matrix nucleotide substitutions based on methods $H K Y+G+I$

\begin{tabular}{ccccc}
\hline $\begin{array}{c}\text { Dari/ke- } \\
\text { From/to }\end{array}$ & $\mathrm{A}$ & $\mathrm{T}$ & $\mathrm{C}$ & $\mathrm{G}$ \\
\hline $\mathrm{A}$ & - & 0.0681 & 0.0586 & $\mathbf{0 . 0 7 7 8}$ \\
$\mathrm{T}$ & 0.0568 & - & $\mathbf{0 . 1 6 8 4}$ & 0.0396 \\
$\mathrm{C}$ & 0.0568 & $\mathbf{0 . 1 9 5 8}$ & - & 0.0396 \\
$\mathrm{G}$ & $\mathbf{0 . 1 1 1 8}$ & 0.0681 & 0.0586 & - \\
\hline Keterangan (Note): Bold= subtitusi transitional; italic= subtitusi transversal \\
$\begin{array}{l}\text { Bold= transitional subtitutions; italic= transversional } \\
\text { substitutions }\end{array}$
\end{tabular}


Tabel 2. Perbedaan genetik intragrup dan standar deviasi

Table 2. Genetic divergences intragroup (OTU) and standard deviation

\begin{tabular}{|c|c|c|c|}
\hline Grup/OTU & $\begin{array}{l}\text { Perbedaan genetik } \\
\text { intra grup } \\
\text { Maximum divergence } \\
\text { within group }\end{array}$ & $\begin{array}{l}\text { Persentase } \\
\text { Percentage }(\%)\end{array}$ & $\begin{array}{c}\text { Standar } \\
\text { deviasi } \\
\text { Estimated } \\
\text { standard error }\end{array}$ \\
\hline Desmopuntius pentazona & 0.008 & 0.8 & 0.006 \\
\hline Desmopuntius hexazona & 0.068 & $6.8^{*)}$ & 0.010 \\
\hline Desmopuntius rombochelatus & $n / c$ & $n / c$ & $n / c$ \\
\hline Puntius tetrazona & 0.002 & 0.2 & 0.002 \\
\hline Osteocelus & 0.002 & 0.2 & 0.004 \\
\hline Rasbora sp.-GKN & 0.007 & 0.7 & 0.004 \\
\hline Pectenocypris sp.-BB & 0.002 & 0.2 & 0.002 \\
\hline Pectenocypris sp.-TS & 0.002 & 0.2 & 0.002 \\
\hline Rasbora sp.-GMR & 0.120 & $12.0^{*}$ & 0.018 \\
\hline Rasbora doriocellata & 0.003 & 0.3 & 0.002 \\
\hline Betta akademis & 0.003 & 0.3 & 0.004 \\
\hline Mystus bimaculatus & 0.002 & 0.2 & 0.001 \\
\hline Kryptopterus impok & 0.117 & $11.7^{*}$ & 0.019 \\
\hline Silichtys phaiosoma & 0.003 & 0.3 & 0.002 \\
\hline Crossocheilus siamensis & 0.013 & 0.1 & 0.004 \\
\hline Epalzeorhynchos kalopterus & 0.003 & 0.3 & 0.002 \\
\hline Syncrossus hymenophysa & 0.003 & 0.3 & 0.002 \\
\hline Pangio kuhlii & 0.001 & 0.1 & 0.001 \\
\hline Rasbora harlequin & 0.003 & 0.3 & 0.002 \\
\hline Rasbora maculata & 0.260 & $26.0^{*}$ & 0.038 \\
\hline Peltrobagus & 0.006 & 0.6 & 0.003 \\
\hline Halostoma taminski & 0.052 & $5.2^{*}$ & 0.012 \\
\hline Anabas testudineus & 0.002 & 0.2 & 0.001 \\
\hline Sphairichtys ospronemodes & 0.015 & 1.5 & 0.005 \\
\hline Puntius & $\mathrm{n} / \mathrm{c}$ & $n / c$ & $n / c$ \\
\hline Chaka bangkanensis & $\mathrm{n} / \mathrm{c}$ & $\mathrm{n} / \mathrm{c}$ & $n / c$ \\
\hline Luceocephalus pulcer & $\mathrm{n} / \mathrm{c}$ & $n / c$ & $\mathrm{n} / \mathrm{c}$ \\
\hline Mystus Thailand & 0.002 & 0.2 & 0.004 \\
\hline Datnoides microlepis & 0.001 & 0.1 & 0.004 \\
\hline Leiocassis porcilopterus & 0.001 & 0.1 & 0.004 \\
\hline
\end{tabular}

Keterangan (Note): OTU = Operational Taxonomic Unit; ${ }^{*}=$ perbedaan genetik $>3 \%$

Note: $\quad$ OTU $=$ Operational Taxonomic Unit; ${ }^{*}=$ genetic divergences $>3 \%$

spesies (4,17\%); dan Bagridae empat spesies (16,67\%) (Gambar 1).

Mengacu pada nilai bootstrap masing-masing OTU yang berkisar antara 87 hingga 99 dapat dikatakan bahwa pengelompokan spesies tersebut memiliki tingkat kesamaan yang cukup tinggi. Namun beberapa spesies dari Cyprinide seperti Seluang garis merah dan Rasbora maculata menunjukkan terjadinya fenomena cryptic spesies (spesies yang samar). Sebagian besar ikan air tawar yang mendiami perairan tropis terutama lahan gambut memiliki kemampuan adaptasi yang cukup tinggi sehingga terjadi perubahanperubahan secara morfologi (radiation of morphologycal) yang mengarah fenomena cryptik spesies. Cyprinidae merupakan famili yang sangat kompleks dengan penyebaran luas dan keragaman tinggi (Nelson, 2006).

Hubert et al. (2015) telah melakukan kajian komposisi ikan-ikan yang mendiami tiga spot biodiversitas di Indonesia yaitu paparan Sundaland, Walacea, dan Sahul. Wilayah Sundaland didominasi oleh Famili Cyprinidae yaitu 231 spesies dari 241 spesies yang mendiami wilayah Indonesia (95,8\% diikuti oleh Osphronomidae, Gobiidae, Bagdridae, Balontidae, Siluridae, dan Cobitidae. Pada wilayah Walacea dan Sahul masing-masing didominasi oleh famili Gobiidae 


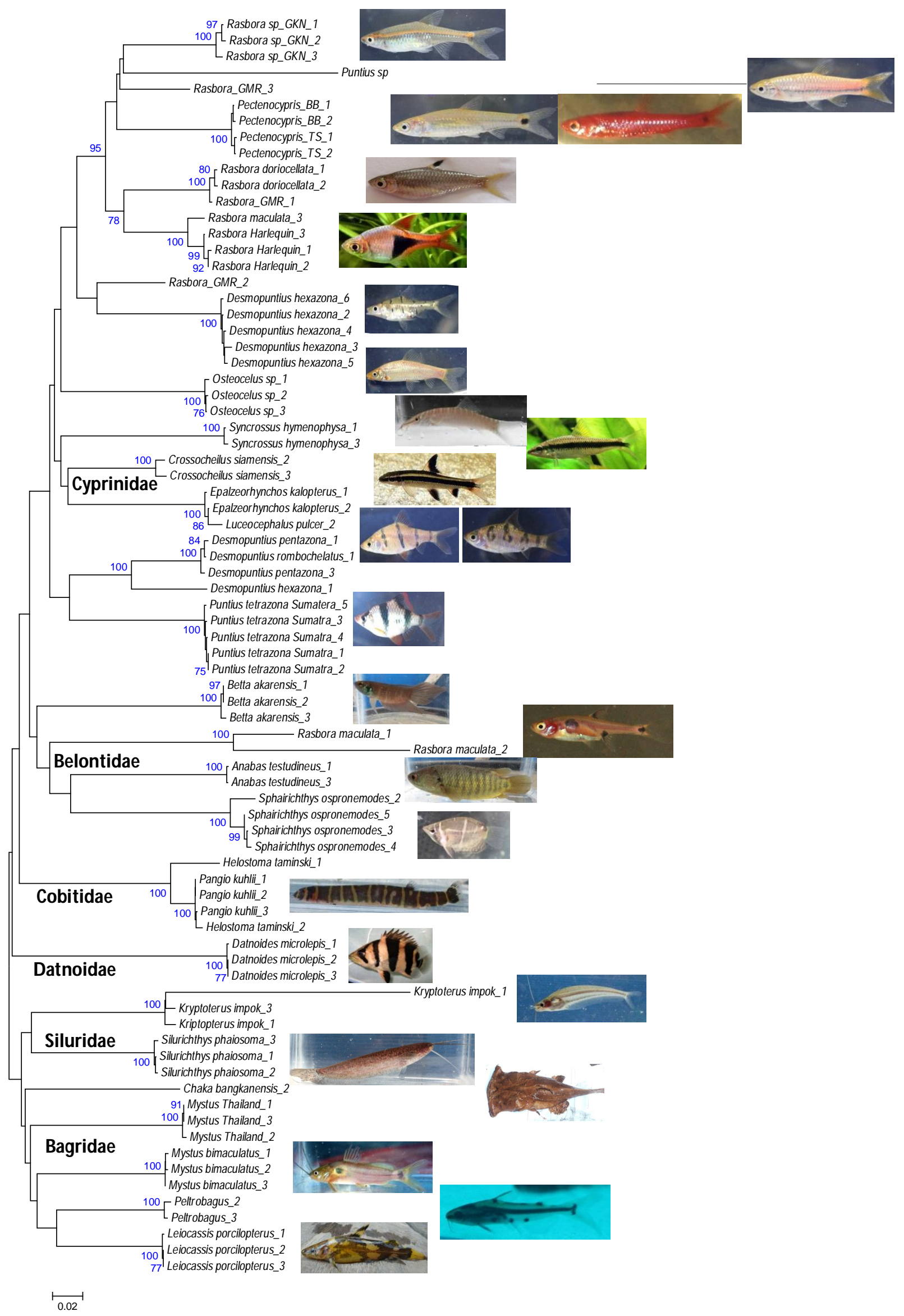

Gambar 1. Dendrogram ikan-ikan yang mendiami lahan gambut berdasarkan gen barcoding COI

Figure 1. Dendrogram DNA barcoding genes (COI) of the fish that inhabit peatland 
(52 spesies) dan Melanitidae (47 spesies). Selanjutnya Huber et al. (2015) juga menjelaskan tingkat endemis ikan yang mendiami paparan Sunda juga mengikuti pola yang sama, yaitu Cyprinidae (135 spesies) dan Osphonomidae (59 spesies).

\section{DNA Barcoding untuk Konservasi Genetik Ikan Hias Lahan Gambut}

Konservasi genetik merupakan upaya mempertahankan keragaman genetik intra-populasi dan intra-spesies, hal ini disebabkan karena dua alasan. Alasan pertama yaitu keragaman genetik sangat diperlukan oleh makhluk hidup untuk beradaptasi, berevolusi, dan melakukan perubahan sehingga dapat menyesuaikan diri dengan perubahan lingkungan yang terjadi secara terus-menerus. Alasan kedua adalah hilangnya keragaman genetik akan menimbulkan potensi inbreeding dan menurunkan kebugaran (fitness) reproduksi (Frankham et al., 2002).

Frankham et al. (2002) menjelaskan bahwa bagian yang sangat penting dalam konservasi genetik adalah kepastian taksonomi baik melalui pendekatan morfologi maupun molekuler. Kepastian taksonomi ini diperlukan untuk beberapa kepentingan di antaranya perlindungan hukum untuk spesies yang terancam punah, peta penyebaran, status spesies endemik atau invasif dan identifikasi spesies yang memiliki nilai ekonomis penting.

Kemampuan gen COI dalam mengidentifikasi spesies-spesies kompleks telah diuji pada beberapa penelitian seperti ikan-ikan famili Cyprinidae (Collins et al., 2012), rainbow (Kadarusman et al., 2012), larva ikan air gambut (Wibowo et al., 2015) dan ikan trout, serta salmon (Rasmussen et al., 2009). Hebert et al. (2003) mempublikasikan primer untuk DNA barcoding mengapit sekuen dengan kriteria sebagai berikut; tingkat evolusi molekuler yang tinggi, tingkat mutasi delesi atau insersi relatif rendah dibandingkan dengan gen 165 rRNA dan 125 rRNA walaupun memiliki kedekatan kekerabatan spesies.

Seiring dengan tingginya tingkat keragaman yang mendiami paparan Sunda (Sundaland), maka aktivitas penangkapan ikan di wilayah ini juga cukup intensif baik untuk kebutuhan konsumsi maupun ikan hias. Tingkat endemisitas ikan di paparan Sunda didominasi oleh ikan-ikan yang mendiami perairan gambut, di mana salah satu karakter ikan yang mendiami perairan tersebut adalah bersifat endemik sehingga rentan terhadap ancaman kepunahan (Hubert et al., 2015; Ng et al., 1994). Oleh karena itu, salah satu upaya konservasi ikan-ikan yang mendiami perairan tersebut adalah dengan memetakan keberadaan ikan-ikan tersebut secara komprehensif. Konsorsium internasional DNA barcoding telah menyiapkan sebuah sistem yang dapat diakses dengan mudah untuk mendapatkan informasi terkait keberadaan ikan-ikan di Indonesia.

Penelitian ini telah berhasil menambahkan data ikan-ikan yang mendiami perairan Indonesia pada perpustakaan DNA barcoding (BOLD SYSTEM). Dengan mengikuti persyatatan yang telah dikeluarkan oleh GenBank, yaitu (1) memiliki sekuen nukleotida sepanjang 500 bp berasal dari situs barcoding yang telah disepakati yaitu COI, (2) amplifikasi mengacu pada primer yang telah ditentukan oleh konsorsium, (3) rekam jejak file dapat diakses secara terbuka, dan (4) penamaan spesies telah mengacu pada dokumen yang telah disepakati.

Melalui BOLD SYSTEM, maka salah satu permasalah status nama ikan-ikan yang mendiami perairan Indonesia telah terselesaikan secara cepat dan otomatis. Pada dekade sebelumnya identifikasi ikan telah menjadi tantangan tersendiri bagi bangsa Indonesia di antaranya (1) Indonesia merupakan negara kepulauan yang terdiri atas kurang lebih 17.000 pulau dan ini menjadi kendala dalam mengelola biodiversitasnya, (2) terkait dinamika politik khusus ikan yang diidentifikasi sebelum tahun 1950 sulit untuk mendapatkan spesimen dan merunut keberadaan ikannya, (3) fenomena "radiation of morphological" di mana terjadi keragaman morfologi namun tidak berdampak pada peningkatan biodiversitas (Hubert et al., 2015).

\section{KESIMPULAN}

Penggunaan marka genetik COI sebagai DNA barcoding telah berhasil mengidentifikasi 26 spesies ikan hias yang mendiami perairan gambut. Keragaman genetik intra-spesies yang cukup tinggi menunjukkan kemampuan spesies beradaptasi terhadap lingkungan yang ekstrem. Pengelompokan OTU berdasarkan DNA barcoding memiliki nilai permutasi yang cukup tinggi yaitu 87-99, mengindikasikan DNA barcoding sebagai penanda genetik hingga tingkat spesies.

\section{UCAPAN TERIMA KASIH}

Terima kasih disampaikan kepada Yayasan Mitra Insani (YMI), Sinar Mas Forestry dan Bapak Ipong, serta Bapak Anwar selaku pengumpul ikan hias di Provinsi Riau dan Jambi yang telah membantu pengumpulan sampel untuk penelitian ini. Dr. Nicolas Hubert atas bimbingan dalam mengakses www. BoldSytem.org. Penelitian ini dibiayai dari APBN melalui DIPA Balitbang Budidaya Ikan Hias tahun 2015. 


\section{DAFTAR ACUAN}

Blaxter, M. (2003). Molecular systematics: Counting angels with DNA, Nature, 421, 122-124.

Collins, R.A., Armstrong, K.F., Meier, R., Yi, Y., \& Brown, S.D.J. (2012). Barcoding and border biosecurity: identifying cyprinid fishes in the aquarium trade. PLOS ONE, 7(1), e28381. Doi: 10.1371/journal.pone.0028381.

Frankham, R., Ballau, J.D., \& Briscoes, D.A. (2002). Introduction to conservation genetic. Cambridge University Press.

Giam, X., Koh, L.P., Tan, H.H., Miettinen, J., Tan, H.T.W., \& Ng, P.K.L. (2012). Global extinctions of freshwater fishes follow peatland conversion in Sundaland. Front. Ecol. Environ., 10(9), 465-470. Doi:10.1890/110182.

Hebert, P.D.N., Cywinska, A., Ball, S.L., \& DeWaard, J.R. (2003). Biological identifications through DNA barcodes. Proceedings of the Royal Society of London Series B. Biological Sciences, 270, 313-321.

Hubert, N., Kadarusman, Wibowo, A., Busson, F., Caruso, D., Sulandari, S., Nafiqoh, N., Pouyaud, L., Rüber, L., Avarre, J.C., Herder, F., Hanner, R., Keith, P., \& Hadiaty. R.K. (2015). DNA barcoding Indonesian freshwater fishes: challenges and prospects. DNA Barcodes, 3, 144-169. Doi: 10.1515/ dna-2015-0018.

Kadarusman, Hubert, N., Hadiaty, R.K., Sudarto, \& Paradis, E. (2012). Cryptic diversity in Indo-Australian rainbowfishes revealed by DNA barcoding: Implications for conservation in a biodiversity hotspot candidate. PLOS ONE, 7(7), e40627. Doi: 10.1371/journal.pone.0040627.

Kotellat, M., Whitten, A.J., Kartikasari, S.N., \& Wirjoatmodjo, S. (1993). Freshwater fishes of western Indonesia and Sulawesi. Periplus Edition.

Mary, R.C.P., Lahiru, S.W., \& Richard, T.C. (2011). Biodiversity and conservation of tropical peat swamp forests. Bioscience, 61(1), 49-57.

Miettinen, J., \& Liew, S.C. (2010). Degradation and development of peatlands in Peninsular Malaysia and in the islands of Sumatra and Borneo since 1990. Land Degrad. Dev., 21, 285-96.

Nelson, J.S. (2006). Fishes of the World (4th ed). John Wiley \& Sons-New Jersey. USA, p. 114-115.

Ng, P.K.L., Tay, J.B., \& Lim, K.K.P. (1994). Diversity and conservation of blackwater fishes in Peninsular Malaysia, particularly in the North Selangor peat swamp forest. Hydrobiologia, 285, 203-18.

Page, S.E., Rieley, J.O., \& Banks, C.J. (2011). Global and regional importance of the tropical peatland carbon pool. Glob. Change Biol., 17, 798-818.

Paul, D.N.H., Sujeevan, R., \& Jeremy, R. (2003). Barcoding animal life: cytochrome c oxidase subunit 1 divergences among closely related species. Proc. R Soc., 270, S96-S99.

Rasmussen, R.S., Morrissey, M.T., \& Hebert, P.D.N. (2009). DNA barcoding of commercially important salmon and trout species (Oncorhynchus and Salmo) from North America. Journal of Agricultural and Food Chemistry, 57, 8379-8385.

Robert, T.R. (1989). The freshwater fishes of western Borneo. California Academy of Science.

Tamura, K., Peterson, D., Peterson, N., Stecher, G., Nei, M., \& Kumar, S. (2011). MEGA5: Molecular Evolutionary Genetics Analysis Using Maximum Likelihood, Evolutionary Distance, and Maximum Parsimony Methods. Mol Biol Evol. doi: 10.1093/ molbev/msr121.

Taylor, H.R., \& Harrist. (2012). Invited technical review: An emergent science onthe brink of irrelevance: areview of thepast 8 years of DNA barcoding. Molecular Ecology Resources, 12, 377388.

Tautz, D., Arctander, P., Minelli, A., Thomas, R.H., \& Vogler, A.P. (2002). DNA points the way ahead in taxonomy. Nature, p. 418-479.

Wibowo, A., Sloterdijk, H., \& Ulrich, S.P. (2015). Identifying Sumatran peat swamp fish larvae through DNA barcoding, evidence of complete life history pattern. $2^{\text {nd }}$ Humboldt Kolleg in conjunction with International Conference on Natural Sciences. Procedia Chemistry, 14, 76-84 


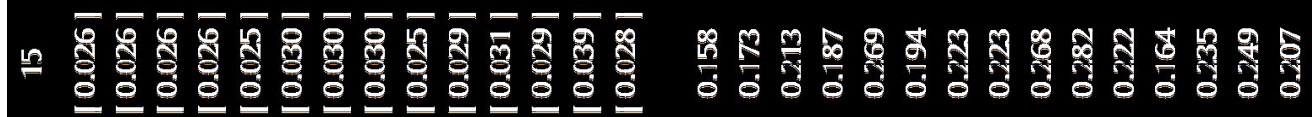

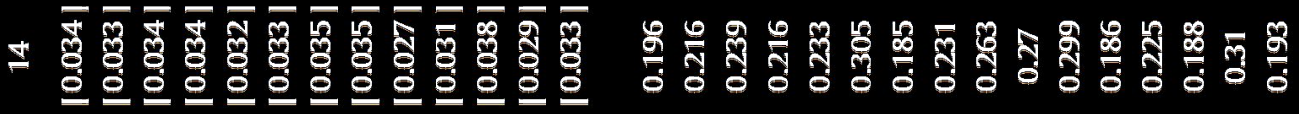

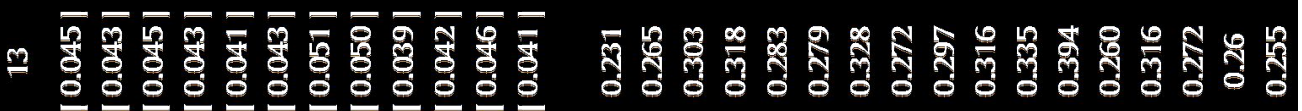

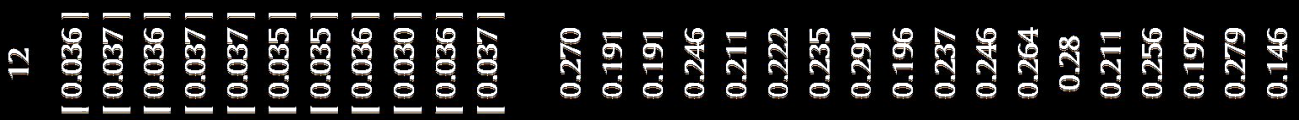

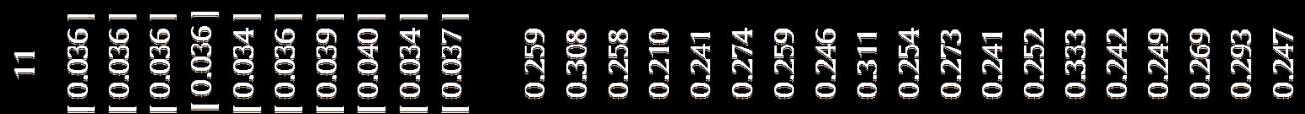

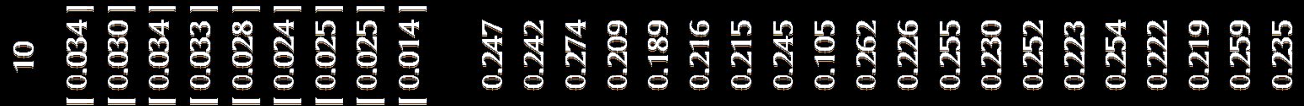

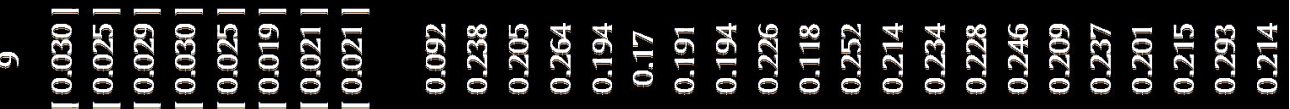

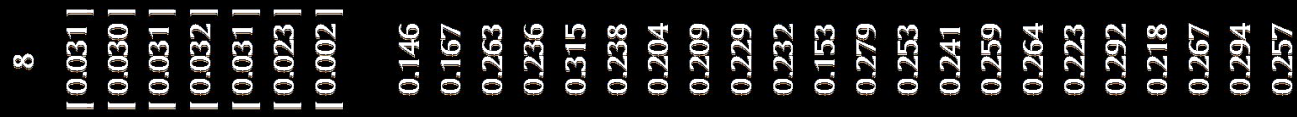

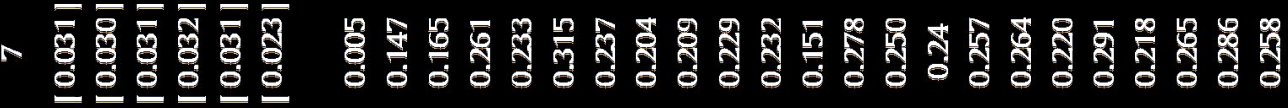

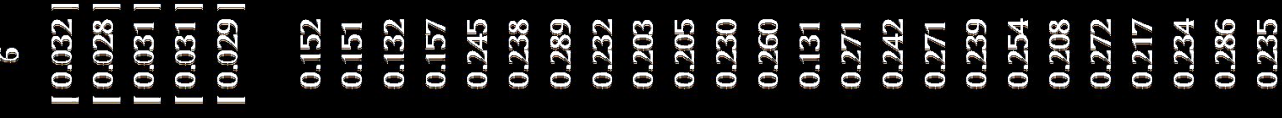

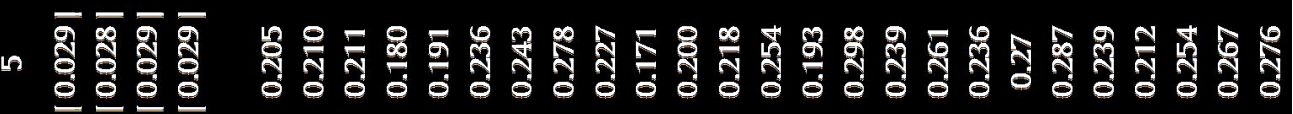

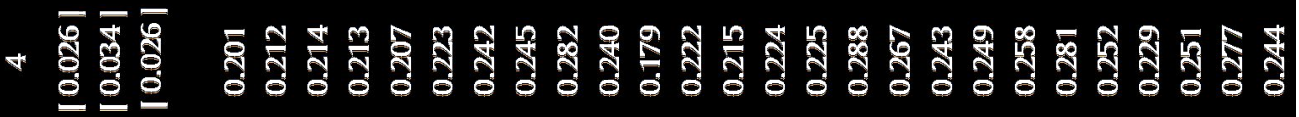

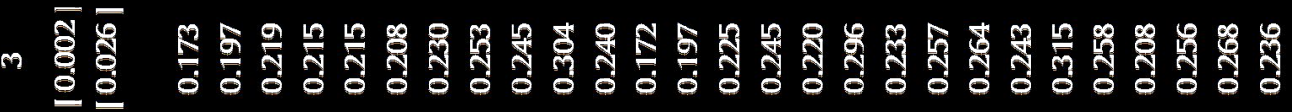

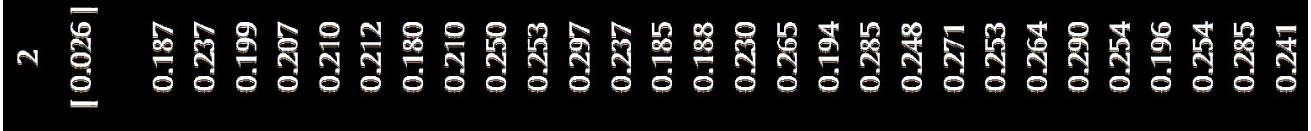

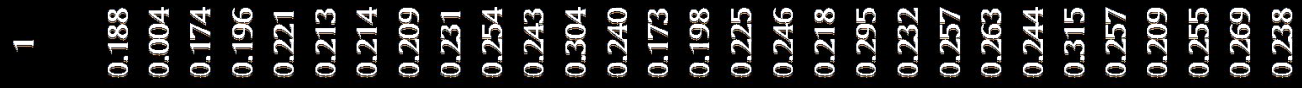




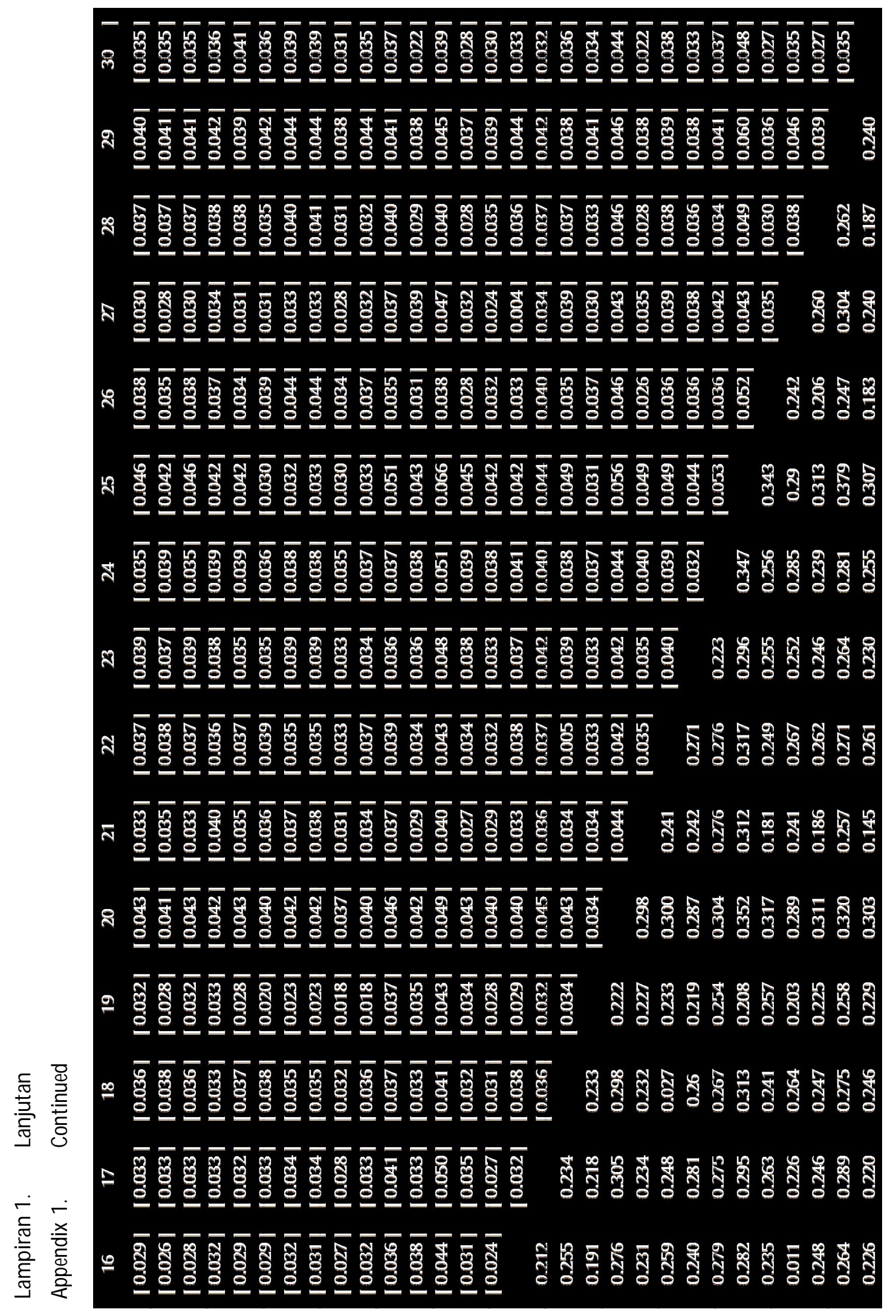

